\title{
PENGARUH PERBANDINGAN TEPUNG SUWEG (Amorphophallus campanulatus) DAN TEPUNG KACANG HIJAU (Vigna radiate) TERHADAP KARAKTERISTIK COOKIES
}

The Effect of Suweg Flour (Amorphophallus campanulatus) and Mung Bean Flour (Vigna radiate) on the Characteristics of Cookies

\author{
Putu Ayu Gaudiya Waisnawi ${ }^{1)}$, Ni Luh Ari Yusasrini ${ }^{2}$, Putu Timur Ina ${ }^{2)}$ \\ ${ }^{1)}$ Mahasiswa Program Studi Ilmu dan Teknologi Pangan, Fakultas Teknologi Pertanian, Unud \\ ${ }^{2)}$ Dosen Program Studi Ilmu dan Teknologi Pangan, Fakultas Teknologi Pertanian, Unud \\ Kampus Bukit Jimbaran, Badung-Bali
}

\begin{abstract}
The purpose of this study was to determine the ratio effect of suweg flour and mung bean flour to produce the best characteristics of cookies. The Completely Randomized Design was used in this study with a comparison of suweg flour with mung bean flour consisting of 5 levels: $90 \%: 10 \%$; $80 \%: 20 \% ; 70 \%: 30 \% ; 60 \%: 40 \%$; $50 \%$ : $50 \%$ The treatment was repeated 3 times for obtain 15 experimental units. Comparison of suweg flour and mung bean flour has a highly significant effect on fat content and crude fiber content and has a significant effect on protein content and carbohydrate levels of cookies. The comparison ratio of $60 \%$ suweg flour and $40 \%$ mung bean flour produces cookies with the best characteristics, namely: $1.37 \%$ moisture content, $2.29 \%$ ash content, $24.44 \%$ fat content, $8.89 \%$ protein content, carbohydrate content $63.01 \%$, crude fiber content $21.78 \%$, color, aroma, texture crispy, preference and overall acceptance were liked.
\end{abstract}

Keywords: suweg flour, mung bean flour, cookies

\section{PENDAHULUAN}

Suweg merupakan tanaman yang tumbuh secara liar dipekarangan, diladang-ladang penduduk tanpa pemeliharaan yang khusus. Suweg telah dikenal oleh hampir semua petani baik di Jawa, Sumatera dan di bagian timur Indonesia. Suweg sangat potensial dikembangkan di Indonesia, dan tanaman suweg sudah dikembangkan di areal Gapoktan (Gabungan Kelompok Tani) yang berada di sekitar KPH (Kesatuan Pemangku Hutan) Perum Perhutani Kendal pada lahan seluas 5 ha. Hasil suweg berkisar antara 30 200 ton/Ha (Matori dalam Turisyawati., 2011).

Suweg mempunyai prospek untuk dikembangkan menjadi tepung umbi maupun pati. Sifat fisikokimia suweg mempunyai amilosa rendah 24,5\% dan amilopektin tinggi 75,5\% (Septiani, dkk., 2015). Adapun komposisi kimia setiap $100 \mathrm{~g}$ suweg adalah protein $1,0 \mathrm{~g}$, lemak $0,1 \mathrm{~g}$, karbohidrat $15,7 \mathrm{~g}$, kalsium $62 \mathrm{mg}$, besi 4,2 g, thiamin 0,07 mg, asam askorbat $5 \mathrm{mg}$ (Sutomo, 2007). Kelemahan dari suweg adalah kandungan kalsium oksalatnya cukup tinggi, sehingga menyebabkan rasa gatal. Untuk mengurangi rasa gatal tersebut dapat dilakukan dengan pengolahan yang tepat salah satunya yaitu diolah menjadi tepung.

Menurut Ekawati dkk., (2016) untuk menghilangkan kalsium oksalat pada suweg dalam pembuatan tepung suweg dapat dilakukan dengan perlakuan perendaman menggunakan larutan asam klorida 0,25\% selama 4 menit kemudian direndam dalam larutan natrium bikarbonat $1 \%$ selama 5 menit

*Korespondensi Penulis:

Email: gaudiyawaisnawi@gmail.com ${ }^{1)}$ 
untuk menetralkan residu asam yang tertinggal. Tepung suweg yang dihasilkan dapat diaplikasikan pada pembuatan cookies.

Cookies merupakan salah satu jenis biskuit yang dibuat dari adonan lunak, berkadar lemak tinggi, relatif renyah bila dipatahkan dan penampang potongannya bertekstur padat (BSN, 1992). Cookies memiliki tesktur yang lebih lembut dan renyah dibanding biskuit, dan cookies memiliki bentuk yang menarik dengan bahan pelengkap lebih bervariasi sehingga rasa cookies pun lebih banyak seperti rasa cokelat, vanilla, strawberry, hingga rasa-rasa yang gurih seperti keju (Anni, 2008). Bahan baku pembuatan cookies secara umum adalah terigu, namun penggunaan terigu bisa diganti dengan bahan lain, seperti tepung suweg, karena produk cookies tidak memerlukan pengembangan yang tinggi. Sukri dkk., (2016) menyatakan bahwa penggunaan terigu bisa diganti $100 \%$ menggunakan tepung walur (Amorphophallus campanulatus) pada pembuatan cookies. Pemanfaatan tepung-tepung lokal seperti tepung suweg sebagai bahan baku pembuatan cookies diharapkan dapat mengurangi ketergantungan masyarakat terhadap penggunaan terigu dan meningkatkan potensi pangan lokal yang tersedia di Indonesia.

Perbaikan nilai gizi cookies dari tepung suweg dapat dilakukam dengan menambahkan tepung kacang hijau. Kacang hijau memiliki kandungan protein yang cukup tinggi yaitu $22 \%$ dan merupakan sumber mineral yang penting antara lain kalsium dan phosphor. Kandungan kacang hijau dalam $100 \mathrm{~g}$ yaitu energi $345 \mathrm{kkal}$, protein $22,2 \mathrm{~g}$, lemak 1,2 g dan karbohidrat 62,9 g, Selain itu, kacang hijau mengandung phospor sebesar $319 \mathrm{mg}$ per $100 \mathrm{~g}$ yang tinggi baik bagi kesehatan tulang dan gigi (Godam, 2013). Kandungan gizi tepung kacang hijau dalam $100 \mathrm{~g}$ adalah protein $31,5 \mathrm{~g}$, lemak 14,3 $\mathrm{g}$ dan serat 35,1 g (Godam, 2013).

Berdasarkan hal tersebut diatas, maka dilakukan penelitian pengaruh perbandingan tepung suweg dan tepung kacang hijau terhadap karakteristik cookies.

\section{METODE PENELITIAN}

\section{Tempat dan Waktu}

Penelitian ini dilaksanakan di Laboratorium Pengolahan Pangan, Laboratorium Analisis Pangan Program Studi Ilmu dan Teknologi Pangan dan Laboratorium Rekayasa Proses dan Pengendalian Mutu Program Studi Teknologi Industri Pertanian Fakultas Teknologi Pertanian Universitas Udayana. Penelitian ini dilaksanakan dari bulan Maret-Mei 2018.

\section{Bahan dan Alat}

Bahan - bahan yang digunakan dalam melaksanakan penelitian ini terdiri dari bahan baku, bahan tambahan, dan bahan kimia. Bahan baku yang digunakan yaitu suweg yang diperoleh di Desa Depaha, Kabupaten Buleleng dan kacang hijau yang diperoleh di Toko Kaja, Denpasar. Sedangkan bahan tambahan terdiri dari gula halus, margarin merk filma royal, susu bubuk, baking powder, yang diperoleh di UD Fenny Denpasar. Bahan kimia yang digunakan dalam melakukan analisis proksimat meliputi $\mathrm{H}_{2} \mathrm{SO}_{4}, \mathrm{NaOH}$, $\mathrm{HCl}$, Heksan, $\mathrm{K}_{2} \mathrm{SO}_{4}$, alkohol $96 \%$, tablet Kjeldahl, asam borat, dan indikator phenolphthalein (PP) .

Alat yang digunakan dalam penelitian ini meliputi botol timbang, oven (Memmert), timbangan analitik ( $A C I S)$, eksikator, cawan porselin, pipet tetes, kompor listrik, muffle (Daihan), labu kjeldahl, Erlenmeyer (Pyrex), kertas saring, benang wol, ekstraksi soxhlet, labu lemak, waterbath (thermology), kertas whatman 42, pisau, waskom, parutan, aluminium foil, loyang, blender (Phillips), ayakan 80 mesh, keranjang, panci, mixer (Electrolux), gelas ukur (Pyrex), kompor gas (Rinnai), termometer, penggiling kayu, cetakan cookies, penggaris, perangkat komputer dan lembar kuisioner untuk uji sensoris. 


\section{Rancangan Percobaan}

Rancangan yang digunakan pada penelitian ini adalah Rancangan Acak Lengkap (RAL) dengan perlakuan perbandingan tepung suweg dan tepung kacang hijau yaitu: P1 (90\% : $10 \%)$, P2 (80\%: 20\%), P3 (70\% : 30\%), P4 $(60 \%: 40 \%)$, P5 (50\% : 50\%). Masing masing perlakuan diulang sebanyak 3 kali sehingga diperoleh 15 unit percobaan. Data yang diperoleh dianalisis dengan sidik ragam dan apabila perlakuan berpengaruh maka dilanjutkan dengan uji Duncan (Gomez dan Gomez, 1995).

\section{Pelaksanaan Penelitian}

Pelaksanaan penelitian ini terdiri dari: pembuatan tepung suweg dan tepung kacang hijau. Bahan yang digunakan kemudian ditimbang sesuai dengan formulanya, seperti terlihat pada Tabel 1 .

Tabel 1. Formula cookies tepung suweg dan tepung kacang hijau

\begin{tabular}{llllll}
\hline Bahan (\%) & P1 & P2 & P3 & P4 & P5 \\
\hline Tepung suweg & 90 & 80 & 70 & 60 & 50 \\
Tepung kacang hijau & 10 & 20 & 30 & 40 & 50 \\
Margarin & 85 & 85 & 85 & 85 & 85 \\
Gula halus & 67 & 67 & 67 & 67 & 67 \\
Baking powder & 0.5 & 0.5 & 0.5 & 0.5 & 0.5 \\
Susu skim & 15 & 15 & 15 & 15 & 15 \\
\hline
\end{tabular}

Keterangan: persentase diatas berdasarkan jumlah tepung suweg dan tepung kacang hijau (100g)

Sumber: Marissa (2010) yang telah dimodifikasi

1. Pembuatan tepung suweg

Umbi suweg yang digunakan sebagai bahan baku tepung adalah umbi yang tua dan telah siap untuk dikonsumsi. Umbi dikupas dan dicuci dengan air lalu ditiriskan, kemudian diparut selanjutnya direndam untuk mereduksi kandungan kalsium oksalat yang dapat menyebabkan rasa gatal pada umbi. Perendaman dilakukan dalam larutan asam klorida $0,25 \%$ selama 4 menit untuk menghilangkan rasa gatal dari suweg. Hasil parutan umbi suweg kemudian ditiriskan dan direndam dalam larutan natrium bikarbonat $1 \%$ selama 5 menit untuk menetralkan residu asam yang tertinggal. Setelah perlakuan perendaman parutan umbi suweg dicuci dengan air mengalir hingga bersih selanjutnya ditiriskan. Hasil parutan umbi suweg dikeringkan dengan oven pada suhu $60^{\circ} \mathrm{C}$ selama 8 jam. Proses dilanjutkan dengan menggiling tepung sampai halus dan kemudian diayak menggunakan ayakan 80 mesh.
2. Pembuatan tepung kacang hijau

Kacang hijau kering dicuci bersih, selanjutnya direndam dalam air selama 3 jam dengan tidak melepas kulit arinya, (kacang hijau yang tenggelam menandakan kualitas biji baik), ditiriskan, kemudian dikeringkan dalam oven pada suhu $60^{\circ} \mathrm{C}$ selama 6 jam. Kacang hijau yang telah kering dihaluskan dengan blender lalu diayak dengan ayakan 80 mesh.

3. Pembuatan cookies

Margarin dan gula halus dicampur dengan mixer selama 2 menit, kemudian ditambahkan tepung suweg dan tepung kacang hijau (sesuai perlakuan), baking powder, susu skim diaduk sampai rata sehingga diperoleh adonan cookies. Adonan yang sudah jadi kemudian diambil sedikit demi sedikit dan adonan digiling menggunakan rolling pan. Adonan dicetak menggunakan alat pencetak cookies, kemudian diletakkan di atas loyang aluminium dan selanjutnya dipanggang dalam oven pada suhu $180^{\circ} \mathrm{C}$ selama 10 menit. 


\section{Variabel yang Diamati}

Variabel yang diamati dalam penelitian menurut Sudarmadji dkk., (1997) ini meliputi kadar air dilakukan dengan metode pengeringan, kadar abu dengan metode pengabuan, kadar protein dengan metode Mikro-Kjeldahl, kadar lemak dengan metode Soxhlet, kadar karbohidrat dengan metode Carbohydrate by different, kadar serat kasar dengan metode hidrolisis asam basa, dan evaluasi sensoris menggunakan uji hedonik warna, tekstur, rasa, aroma, dan penerimaan keseluruhan serta uji skoring terhadap tekstur (Soekarto, 1985).

\section{HASIL DAN PEMBAHASAN}

Hasil analisis proksimat (kadar air, kadar abu, kadar lemak, kadar protein, kadar karbohidrat) dan kadar serat kasar tepung suweg dan tepung kacang hijau yang digunakan dapat dilihat pada Tabel 2

Tabel 2. Nilai rata-rata hasil analisis proksimat (kadar air, kadar abu, kadar lemak, kadar protein, kadar karbohidrat) dan kadar serat kasar dari tepung suweg dan tepung kacang hijau.

\begin{tabular}{lll}
\hline Komponen & Tepung Suweg & Tepung Kacang Hijau \\
\hline Abu (\%) & 2,98 & 3,40 \\
Air (\%) & 3,48 & 3,31 \\
Protein (\%) & 4,24 & 21,45 \\
Lemak (\%) & 5,13 & 4,47 \\
Karbohidrat (\%) & 84,17 & 67,37 \\
Serat Kasar (\%) & 13,58 & 31,52 \\
\hline
\end{tabular}

\section{Hasil Analisis Cookies}

Hasil penelitian nilai rata-rata (kadar air, kadar abu dan kadar lemak) cookies dapat dilihat pada Tabel 3 dan nilai rata-rata (kadar protein, kadar karbohidrat dan kadar serat kasar) cookies dapat dilihat pada Tabel 4.

Tabel 3. Nilai rata-rata kadar air, kadar abu, dan kadar lemak dari cookies.

\begin{tabular}{clll}
\hline Perlakuan & $\begin{array}{l}\text { Kadar } \\
\text { Air (\%bb) }\end{array}$ & Kadar Abu (\%bb) & Kadar Lemak (\%bb) \\
\hline P1 & $1,68 \pm 0,24 \mathrm{a}$ & $1,96 \pm 0,41 \mathrm{a}$ & $27,79 \pm 0,59 \mathrm{a}$ \\
P2 & $1,55 \pm 0,17 \mathrm{a}$ & $2,18 \pm 0,20 \mathrm{a}$ & $26,98 \pm 0,76 \mathrm{a}$ \\
P3 & $1,47 \pm 0,13 \mathrm{a}$ & $2,24 \pm 0,12 \mathrm{a}$ & $26,10 \pm 1,12 \mathrm{ab}$ \\
P4 & $1,37 \pm 0,09 \mathrm{a}$ & $2,29 \pm 0,14 \mathrm{a}$ & $24,44 \pm 1,66 \mathrm{~b}$ \\
P5 & $1,28 \pm 0,04 \mathrm{a}$ & $2,40 \pm 0,14 \mathrm{a}$ & $21,51 \pm 0,69 \mathrm{c}$ \\
\hline
\end{tabular}

Keterangan : Nilai rata - rata yang diikuti oleh huruf yang berbeda pada kolom yang sama menunjukkan berbeda nyata pada Uji Duncan $(\mathrm{P}<0,05)$

\section{Kadar Air}

Hasil sidik ragam menunjukkan bahwa perbandingan tepung suweg dengan tepung kacang hijau berpengaruh tidak nyata $(\mathrm{P}>0,05)$ terhadap kadar air cookies. Kadar air cookies berkisar dari 1,28\% - 1,68\%. Hal ini disebabkan karena kadar air bahan baku yaitu tepung suweg $(3,48 \%)$ dan tepung kacang hijau (3,31\%) tidak jauh berbeda (Tabel 2). Besarnya nilai kadar air menurut standar mutu cookies maksimal 5\% bb (Anon. 1992), jadi kadar air cookies yang dihasilkan telah memenuhi standar mutu cookies.

\section{Kadar Abu}

Hasil sidik ragam menunjukkan bahwa perbandingan tepung suweg dengan tepung kacang hijau berpengaruh tidak nyata $(\mathrm{P}>0,05)$ terhadap kadar abu cookies. Kadar abu cookies berkisar dari 1,96\% - 2,40\%. Hal 
ini disebabkan karena kadar abu bahan baku tidak jauh berbeda, yaitu kadar abu pada tepung suweg $(2,98 \%)$ dan kadar abu tepung kacang hijau (3,40\%) (Tabel 2). Kadar abu dari hasil penelitian belum memenuhi syarat SNI yaitu maksimal 1,5\%.

\section{Kadar Lemak}

Hasil sidik ragam menunjukkan bahwa perbandingan tepung suweg dengan tepung kacang hijau berpengaruh sangat nyata $(\mathrm{P}<0,01)$ terhadap kadar lemak cookies. Terlihat pada Tabel 3, kadar lemak cookies tertinggi diperoleh pada perlakuan P1 $(90 \%$ tepung suweg : 10\% tepung kacang hijau) yaitu $27,79 \%$ serta berbeda tidak nyata dengan perlakuan P2 dan P3 dan terendah pada perlakuan P5 (50\% tepung suweg : 50\% tepung kacang hijau) yaitu $21,51 \%$. Semakin tinggi penambahan tepung kacang hijau maka kadar lemak semakin menurun. Hal ini dikarenakan tepung kacang hijau mempunyai kadar lemak $(4,47 \%)$ dan tepung suweg $(5,13 \%)$ (Tabel 2). Menurut SNI, kadar lemak cookies minimum $9,5 \%$ jadi kadar lemak cookies yang dihasilkan telah memenuhi standar mutu cookies.

Tabel 4. Nilai rata-rata kadar protein, kadar karbohidrat, dan kadar serat kasar dari cookies.

\begin{tabular}{clll}
\hline Perlakuan & Kadar Protein $(\% \mathrm{bb})$ & $\begin{array}{l}\text { Kadar } \\
\text { Karbohidrat }(\% \mathrm{bb})\end{array}$ & Kadar Serat Kasar $(\% \mathrm{bb})$ \\
\hline P1 & $7,10 \pm 0,72 \mathrm{c}$ & $61,47 \pm 1,08 \mathrm{~b}$ & $12,33 \pm 0,71 \mathrm{~d}$ \\
P2 & $7,68 \pm 0,67 \mathrm{bc}$ & $61,62 \pm 0,45 \mathrm{~b}$ & $13,65 \pm 1,29 \mathrm{~cd}$ \\
P3 & $8,33 \pm 0,69 \mathrm{bc}$ & $61,85 \pm 0,76 \mathrm{~b}$ & $15,06 \pm 0,93 \mathrm{c}$ \\
P4 & $8,89 \pm 0,83 \mathrm{~b}$ & $63,01 \pm 0,88 \mathrm{ab}$ & $21,78 \pm 1,31 \mathrm{~b}$ \\
P5 & $10,40 \pm 0,49 \mathrm{a}$ & $64,41 \pm 1,20 \mathrm{a}$ & $27,25 \pm 1,26 \mathrm{a}$ \\
\hline
\end{tabular}

Keterangan : Nilai rata - rata yang diikuti oleh huruf yang berbeda pada kolom yang sama menunjukkan berbeda nyata

\section{Kadar Protein} pada Uji Duncan $(\mathrm{P}<0,05)$.

Hasil sidik ragam menunjukkan bahwa perbandingan tepung suweg dengan tepung kacang hijau berpengaruh nyata $(\mathrm{P}<0,05)$ terhadap kadar protein cookies. Terlihat pada Tabel 4 kadar protein cookies tertinggi diperoleh pada perlakuan P5 (50\% tepung suweg dan 50\% tepung kacang hijau) yaitu $10,40 \%$ dan terendah pada perlakuan P1 $(90 \%$ tepung suweg dan $10 \%$ tepung kacang hijau) yaitu $7,10 \%$ dan berbeda tidak nyata dengan perlakuan P2 dan P3. Hal ini disebabkan karena kandungan protein tepung suweg lebih rendah dibandingkan tepung kacang hijau. Tepung suweg mempunyai kadar protein $(4,24 \%)$ dan tepung kacang hijau $(21,45 \%)$ (Tabel 2).

\section{Kadar Karbohidrat}

Hasil sidik ragam menunjukkan bahwa perbandingan tepung suweg dengan tepung kacang hijau berpengaruh nyata $(\mathrm{P}<0,05)$ terhadap kadar karbohidrat cookies. Terlihat pada Tabel 4 kadar karbohidrat cookies tertinggi diperoleh pada perlakuan P5 (50\% tepung suweg : $50 \%$ tepung kacang hijau) yaitu $64,41 \%$ dan terendah pada perlakuan P1 (90\% tepung suweg : $10 \%$ tepung kacang hijau) yaitu $61,47 \%$ serta berbeda tidak nyata dengan perlakuan P2, P3, dan P4. Kadar karbohidrat dari hasil penelitian belum memenuhi persyaratan SNI yaitu minimal $70 \%$. Kadar karbohidrat yang dihitung secara by difference dipengaruhi oleh komponen nutrisi lain, semakin rendah komponen nutrisi lain maka kadar karbohidrat akan semakin tinggi. Begitu juga sebaliknya semakin tinggi komponen nutrisi lain maka kadar karbohidrat akan semakin rendah. Komponen nutrisi yang mempengaruhi besarnya kandungan karbohidrat diantaranya adalah kandungan air, abu, protein dan lemak. 


\section{Kadar Serat Kasar}

Hasil sidik ragam menunjukkan bahwa perbandingan tepung suweg dengan tepung kacang hijau berpengaruh sangat nyata $(\mathrm{P}<0,01)$ terhadap kadar serat kasar cookies. Terlihat pada Tabel 4 kadar serat kasar cookies tertinggi diperoleh pada perlakuan P5 (50\% tepung suweg dan 50\% tepung kacang hijau) yaitu $27,25 \%$ dan terendah pada perlakuan P1 (90\% tepung suweg dan 10\% tepung kacang hijau) yaitu $12,33 \%$. Semakin tinggi penambahan tepung suweg maka kadar serat kasar semakin menurun. Hal ini dikarenakan tepung suweg mempunyai kadar serat kasar $(13,58 \%)$ dan tepung kacang hijau $(31,52 \%)$ serta dapat dilihat pada Tabel 2 . Kadar serat kasar belum memenuhi syarat SNI yaitu maksimal $0,5 \%$.

Tabel 5. Nilai rata-rata uji hedonik warna, aroma, tekstur, rasa dan penerimaan keseluruhan cookies.

\begin{tabular}{|c|c|c|c|c|c|}
\hline \multirow{2}{*}{ Perlakuan } & \multicolumn{5}{|c|}{ Nilai rata - rata uji hedonik } \\
\hline & Warna & Aroma & Tekstur & Rasa & $\begin{array}{l}\text { Penerimaan } \\
\text { Keseluruhan }\end{array}$ \\
\hline P1 & $5,33 \pm 0,82 \mathrm{a}$ & $5,67 \pm 0,90 \mathrm{a}$ & $5,60 \pm 1,06 \mathrm{a}$ & $5,80 \pm 0,86 a$ & $5,33 \pm 0,82 \mathrm{a}$ \\
\hline $\mathrm{P} 2$ & $5,20 \pm 0,77 \mathrm{a}$ & $5,53 \pm 0,99 \mathrm{a}$ & $5,47 \pm 0,92 \mathrm{a}$ & $5,53 \pm 0,83 a$ & $5,60 \pm 0,83 a$ \\
\hline P3 & $5,53 \pm 0,64 \mathrm{a}$ & $5,47 \pm 0,64$ a & $6,07 \pm 0,70 \mathrm{a}$ & $5,73 \pm 0,46 a$ & $5,67 \pm 0,62 \mathrm{a}$ \\
\hline $\mathrm{P} 4$ & $5,73 \pm 1,10 \mathrm{a}$ & $5,80 \pm 1,08 \mathrm{a}$ & $6,00 \pm 0,85 \mathrm{a}$ & $6,07 \pm 1,16 \mathrm{a}$ & $5,87 \pm 0,83 \mathrm{a}$ \\
\hline P5 & $5,93 \pm 0,80 a$ & $5,47 \pm 1,13 \mathrm{a}$ & $6,07 \pm 0,70 \mathrm{a}$ & $6,07 \pm 0,59 \mathrm{a}$ & $5,73 \pm 0,88 \mathrm{a}$ \\
\hline
\end{tabular}

Keterangan : Nilai rata - rata yang diikuti oleh huruf yang berbeda pada kolom yang sama menunjukkan berbeda nyata pada Uji Duncan $(\mathrm{P}<0,05)$.

$\begin{array}{llll}\text { Kriteria } & : \text { 1: sangat tidak suka } & \text { 2: tidak suka } & \text { 3: agak tidak suka } \\ & \text { 4: biasa } & 5 \text { : agak suka } & \text { 6: suka } \\ & \text { 7: sangat suka } & & \end{array}$

Tabel 6. Nilai rata-rata uji skoring tekstur cookies.

Perlakuan

P1

$\mathrm{P} 2$

P3

$\mathrm{P} 4$

P5
Nilai rata - rata uji skoring

Keterangan : Nilai rata - rata yang diikuti oleh huruf yang berbeda pada kolom yang sama menunjukkan berbeda nyata pada Uji Duncan $(\mathrm{P}<0,05)$.

Kriteria $\quad: 1$ : sangat tidak renyah 3 : agak tidak renyah

2: tidak renyah

4: renyah

5: sangat renyah

\section{Warna}

Hasil sidik ragam menunjukkan bahwa perbandingan tepung suweg dengan tepung kacang hijau berpengaruh tidak nyata ( $\mathrm{P}>0,05)$ terhadap warna (uji hedonik) cookies. Tabel 5 menunjukkan penerimaan terhadap warna cookies adalah suka.

\section{Aroma}

Hasil sidik ragam menunjukkan bahwa perbandingan tepung suweg dengan tepung kacang hijau berpengaruh tidak nyata ( $\mathrm{P}>0,05)$ terhadap aroma (uji hedonik) cookies. Tabel 5 menunjukkan penerimaan terhadap warna cookies adalah agak suka. 


\section{Tekstur}

Hasil sidik ragam menunjukkan bahwa perbandingan tepung suweg dengan tepung kacang hijau berpengaruh tidak nyata ( $\mathrm{P}>0,05)$ terhadap tekstur (uji hedonik) cookies. Tabel 5 menunjukkan penerimaan terhadap tekstur cookies adalah suka.

Hasil sidik ragam menunjukkan bahwa perbandingan tepung suweg dengan tepung kacang hijau berpengaruh tidak nyata $(\mathrm{P}>0,05)$ terhadap tekstur (uji skoring) cookies. Tabel 6 menunjukkan penerimaan terhadap tekstur uji skoring adalah renyah.

\section{Rasa}

Hasil sidik ragam menunjukkan bahwa perbandingan tepung suweg dengan tepung kacang hijau berpengaruh tidak nyata $(\mathrm{P}>0,05)$ terhadap rasa (uji hedonik) cookies. Terlihat pada Tabel 5 menunjukkan penerimaan terhadap rasa cookies adalah suka.

\section{Penerimaan Keseluruhan}

Hasil sidik ragam menunjukkan bahwa perbandingan tepung suweg dengan tepung kacang hijau berpengaruh tidak nyata $(\mathrm{P}>0,05)$ terhadap penerimaan keseluruhan cookies. Terlihat pada Tabel 5 menunjukkan penerimaan keseluruhan terhadap cookies adalah suka. Penerimaan keseluruhan cookies dipengaruhi oleh beberapa faktor seperti warna, aroma, tekstur dan rasa.

\section{SIMPULAN DAN SARAN}

\section{Simpulan}

Berdasarkan hasil penelitian ini dapat disimpulkan sebagai berikut :

1. Perbandingan tepung suweg dengan tepung kacang hijau berpengaruh sangat nyata terhadap kadar lemak dan kadar serat kasar dan berpengaruh nyata terhadap kadar protein, dan kadar karbohidrat cookies.
2. Perbandingan $60 \%$ tepung suweg dengan $40 \%$ tepung kacang hijau menghasilkan cookies dengan karakteristik terbaik yaitu: kadar air 1,37\%, kadar abu 2,29\%, kadar lemak 24,44\%, kadar protein 8,89\%, kadar karbohidrat 63,01\%, kadar serat kasar $21,78 \%$, warna disukai, aroma disukai, tekstur renyah dan disukai, rasa disukai serta penerimaan keseluruhan disukai

\section{Saran}

Penelitian selanjutnya tentang cookies sebaiknya menggunakan perbandingan $70 \%$ tepung suweg : 30\% tepung kacang hijau sebagai acuan dasar dalam pembuatan cookies.

\section{DAFTAR PUSTAKA}

Anni. 2008. Patiseri. Direktorat Pembinaan Sekolah Menengah Kejuruan. Jakarta

Anonimus. 1992. SNI 01-2973-1992. Syarat Mutu dan Cara Uji Biskuit. Badan Standarisasi Nasional. Jakarta.

Anonimus. 2009. Tabel Komposisi Pangan Indonesia. Persatuan Ahli Gizi Indonesia. Jakarta: PT. Elex Media Komputindo.

Ariantya, F. S. 2016. Kualitas cookies dengan kombinasi tepung terigu, pati batang aren (Arenga pinnata) dan tepung jantung pisang (Musa paradisiacal). Jurnal Universitas Atmajaya Yogyakarta. Fakultas Teknobiologi. Program studi biologi. Yogyakarta.

Buckle, K.A., R.A. Edwards, G.H. Fleet, M. Wooton. 2013. Ilmu Pangan. Universitas Indonesia, Jakarta.

Budijanto, S. 2000. Modul Praktikum Kimia dan Teknologi Lipida. Jurusan 
Teknologi Pangan dan Gizi, IPB, Bogor.

Darwin, P. 2013. Menikmati Gula Tanpa Rasa Takut. Sinar Ilmu, Yogyakarta.

Desrosier, N. W. 1998. Teknologi Pengawetan Pangan. Penerbi Universitas Indonesia (UI-Press). Jakarta.

Ekawati, I G.A. dan Ina, P. T. 2017. Pengembangan produk sereal sarapan berbasis suweg dan kecambah kacang hijau. Laporan Penelitian Hibah Unggulan Program Studi Ilmu dan Teknologi Pangan Fakultas Teknologi Pertanian Universitas Udayana.

Ekawati, I. G. A., P. T. Ina, dan I D. P. Kartika 2016. Aplikasi tepung suweg (Amorphopallus campanulatus) pregelatinisasi dengan tepung kelor (Moringa oleifera) pada pembuatan mie basah. Media Ilmiah Teknologi Pangan, PS Ilmu dan Teknologi PanganVol. 3 (1): 62 - 70, ISSN : 2407-3814. Prog. Pasca Sarjana, Univ. Udayana

Faridah, A., S. Kasmita, Y. Asmar, dan Y. Liswarti . 2008. Patiseri Jilid 3. Jakarta

Faridah, D. N. 2005. Sifat fisiko-kimia tepung suweg (Amorphophallus campanulatus Bl) dan indeks glisemiknya. Jurnal Teknologi Dan Industry Pangan. Vol 16: 254.

Gomez, K. A. dan A. A. Gomez. 1995. Prosedur Statistik Untuk Penelitian Pertanian. UI Press. Jakarta.

Handono, A. P. 2013. Pemanfaatan Tepung Umbi Suweg (Amorphophallus C) Sebagai Substitusi Tepung Terigu dalam Pembuatan Cookies dengan Penambahan Kuning Telur. Skripsi.
Tidak dipublikasikan. Program Studi Teknologi Pangan. Fakultas Teknologi Industry. Universtias Pembangunan Nasional "Veteran" Jawa Timur. Surabaya.

Inglett, G.E. dan S.I. Falkehag . 1979. Dietary Fibers: Chemistry and Nutrition. New York: Academic Press Inc.

Ketaren, S. 2005. Minyak dan Lemak Pangan. UI Press, Jakarta.

Marissa, D. 2010. Formulasi Cookies Jagung Dan Pendugaan Umur Simpan Produk Dengan Pendekatan Kadar Air Kritis. Skripsi. Tidak dipublikasikan. Fakultas Teknologi Pertanian, IPB, Bogor.

Meilgaard, M., G. V. Civille, and B. T. Carr. 2000. Sensory Evaluation Techniques. Boca Raton, Florida : CRC Press.

Muchtadi T. R. dan Sugiyono. 1992. Petunjuk Laboratorium Ilmu Pengetahuan Bahan Pangan. Pusat Antar Universitas Pangan Dan Gizi IPB, Bogor.

Pitojo, S. 2007. Suweg. Yogjakarta: Kanisius.

Prameswari, R. D. dan T. Estiasih 2013. Pemanfaatan tepung gembili (dioscorea esculenta L.) dalam pembuatan cookies. Jurnal pangan dan argoindustri vol. 1(1): 115-128.

Septiani, D., Y. Hendrawan, dan R. Yulianingsih. 2015. Uji Karakteristik Fisik, Kimia dan Organoleptik Pembuatan Tepung Umbi Suweg (Amorphophallus campanulatus B) Sebagai Bahan Pangan Alternatif. Jurnal Bioproses Komoditas Tropis Volume 3 No.1.

Soekarto, S. T. 1985. Penilaian Organoleptik untuk Industri Pangan dan Hasil 
Pertanian. Bhratara Karya Aksara. Jakarta.

Sudarmadji, S., B. Haryono, dan Suhardi. 1997. Prosedur Analisis Bahan Makanan dan Pertanian. Liberty. Yogyakarta.

Sukri, N., F. Kusnandar, E. H. Purnomo, dan Risfaheri. 2016. Aplikasi tepung walur (amorphophallus campanulatus var. sylvetris) dalam pembuatan mie dan cookies. Jurnal penelitian pangan vol. 1.1. P - ISSM: 2528-3537; E - ISSN: 2528-5157. DOI: 10.24198/jp2.2016.vol 1.1.09. website: www.jurnal.unpad.ac.id/jp2

Triwitono, P., Y. Marsono, A. Murdiati, dan D. W. Marseno. 2017. Isolasi dan karakterisasi pati kacang hijau (Vigna radiate L.) beberapa varietas lokal Indonesia. AGRITECH, Vol. 37 (2)

Turisyawati, R. 2011. Pemanfaatan tepung suweg (amorphophallus campanulatus) sebagai substitusi tepung terigu pada pembuatan cookies. Skripsi. Fakultas pertanian. Universitas Sebelas Maret, Surakarta.

Winarno, F. G. 1985. Kimia Pangan dan Gizi. Gramedia Pustaka Utama, Jakarta.

Winarno, F.G., dan S. Koswara. 2002. IlesIles dan Hasil Olahannya. MBrioPress. Bogor. 